\title{
Communication
}

\section{An Unusual Bismuth Ethanedisulfonate Network}

\section{Fabienne Gschwind * and Martin Jansen}

Max Planck Institute for Solid State Research, Heisenbergstrasse 1, 70569 Stuttgart, Germany; E-Mail: m.jansen@fkf.mpg.de

* Author to whom correspondence should be addressed; E-Mail: f.gschwind@fkf.mpg.de; Tel.: +49-711-689-1409; Fax: +49-711-689-1502.

Received: 11 June 2012; in revised form: 16 July 2012 / Accepted: 14 September 2012 /

Published: 28 September 2012

\begin{abstract}
The three dimensional bismuth ethanedisulfonate framework $\mathrm{Bi}\left(\mathrm{O}_{3} \mathrm{SC}_{2} \mathrm{H}_{4} \mathrm{SO}_{3}\right)_{1.5}\left(\mathrm{H}_{2} \mathrm{O}\right)_{2}$ was synthesized under hydrothermal conditions using the bidentate ligand 1,2-ethanedisulfonate and then characterized through X-ray diffraction and elemental analyses. The bismuth cation coordinates at three different ethanedisulfonate ligands and has a coordination number of eight, which is accompanied by a distorted square antiprismatic configuration. Here, we report on the crystal structure of this bismuth metal-organic framework and its coordination behavior, which has thus far not been reported in heavier main group elements.
\end{abstract}

Keywords: main group chemistry; bismuth complex; ethanedisulfonate; MOF

\section{Introduction}

Bismuth(III) complexes are used in a variety of fields including biology and medicine [1,2], materials chemistry [3,4], and catalysis [5]. For this reason, the synthesis of bismuth metal-organic frameworks (MOFs) has received considerable attention [6]. A handful of bismuth organic frameworks exist, which have a broad range of structures due to their different molecular topologies [7,8]. By varying the set of donor atoms in the organic ligand, it is possible to enlarge this growing class of organometallic compounds. The formation of such frameworks depends significantly on the dimension of the internal cavity, rigidity of the ligands, nature of the electronegative atoms, and complex forming properties of the anion that is involved in the coordination bonding [6]. Generally, $\mathrm{Bi}^{3+}$ with its ionic radius of $1.16 \AA$ [9] has one inert $6 \mathrm{~s}^{2}$ electron pair and forms non-transition metal center complexes with 
higher coordination-number atoms. Therefore, bismuth is predestined to form higher dimensionality cationic frameworks. The well-studied hydrolysis behavior of $\mathrm{Bi}^{3+}$ makes it an especially desirable system for conducting hydrothermal studies on $\left[\mathrm{Bi}_{6} \mathrm{O}_{4}(\mathrm{OH})_{4}\left(\mathrm{H}_{2} \mathrm{O}\right)_{2}\right]\left[\left(\mathrm{CH}_{2}\right)_{2}\left(\mathrm{SO}_{3}\right)_{2}\right]_{3}$ and $\left[\mathrm{Bi}_{9} \mathrm{O}_{8}(\mathrm{OH})_{6}\right]\left[\mathrm{CF}_{3} \mathrm{SO}_{3}\right]_{5}[10]$. Crystalline hybrid materials composed of main group elements are mostly based on metal carboxylates [11-14] and phosphonates [15,16], for further references please refer to Cambridge database [17]. The nature of sulfonate ligands has been less thoroughly investigated in terms of their ability to function as an organic linker in main group MOFs and coordination polymers. However, they may be used in potentially interesting applications such as gas separation, storage, as well as catalysis [18,19]. In particular, porous hybrid transition metal compounds based on carboxylates [20] and phosphonates $[17,21,22]$ have attracted widespread interest in the past few years. However, there exist few MOFs that entail heavier main group elements with sulfonate linker ligands, for instance lead 4-sulfobenzoate complexes [23,24] and the wide range of tin disulfonic MOFs [25].

Research on bismuth based MOFs is rare [6-8]. Even so, some examples of compounds with diethanesulfonate ligands [10,26-31] can be found in the Cambridge Database [17]. For instance works about $\mathrm{Ag}$ and $\mathrm{Cu}$ ethandisulfonate complexes [27,28], bismuth clusters [10] or also mixed ligand cadmium complexes [32] to name only a few examples. Consequently, we would like to report on a three-dimensionally bismuth coordination polymer that encompasses a new structure type, which has not been observed, to the best of our knowledge, in any other MOF composed of heavier main group elements.

\section{Results and Discussion}

The colorless crystals of $\mathrm{Bi}\left(\mathrm{O}_{3} \mathrm{SC}_{2} \mathrm{H}_{4} \mathrm{SO}_{3}\right)_{1.5}\left(\mathrm{H}_{2} \mathrm{O}\right)_{2}$ (1) crystallize in the space group $P 2_{1} / \mathrm{c}$. The asymmetric unit, shown in Figure 1, consists of an eight-coordinated bismuth cation, at which one and a half moieties of the 1,2-ethanedisulfonate ligand are coordinated, and two water molecules. The complete compound contains one crystallographic independent $\mathrm{Bi}^{3+}$ ion, which is surrounded by eight oxygen atoms. Six of these oxygen atoms are part of the $\mathrm{R}_{-} \mathrm{SO}_{3}{ }^{-}$groups $(\mathrm{O} 1, \mathrm{O} 3, \mathrm{O} 4, \mathrm{O} 5, \mathrm{O} 7, \mathrm{O} 9)$, and two are coordinated with water molecules (O10 and O11).

Figure 1. Asymmetric unit of $\mathbf{1}$ and the prolongation of the ethanesulfonate ligands, which are drawn in transparency mode (hydrogen atoms are omitted for clarity).

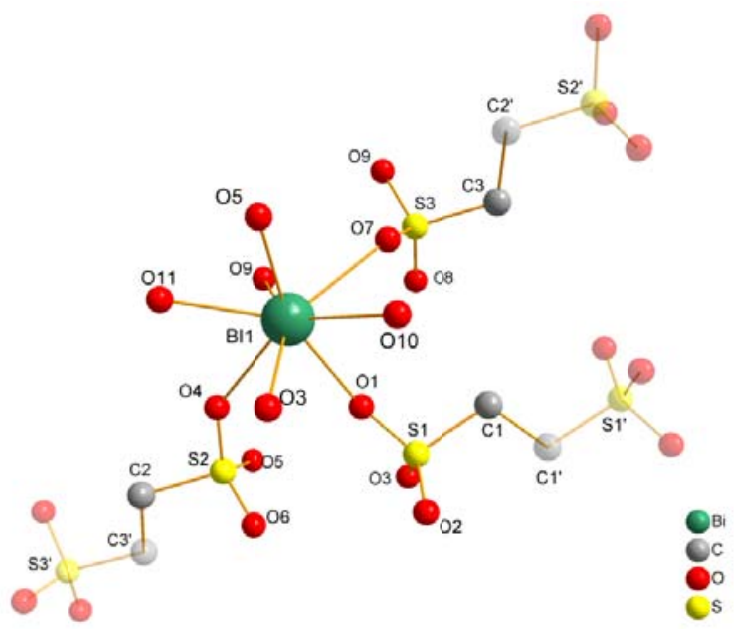


The bridging oxygen atoms $(\mathrm{O} 1, \mathrm{O} 3, \mathrm{O} 4, \mathrm{O} 5, \mathrm{O} 7, \mathrm{O} 9)$ have slightly shorter bond lengths [10] with the bismuth atoms, ranging from 2.324(8) to 2.590(8) $\AA$ (Table 1). The bond lengths between water atoms $(\mathrm{O} 10$ and $\mathrm{O} 11)$ and the bismuth lie in the range of other $\mathrm{Bi}-\mathrm{OH}_{2}$ bond lengths (Cambridge Database: 2.303-3.123 A). A bond valence analysis reveals a value of 2.819 for the bismuth cation, which reflects the slightly insufficient coordination environment of the cation $[33,34]$.

Table 1. Selected bond lengths $(\AA)$ for 1 with estimated standard deviations in parentheses.

\begin{tabular}{ll}
\hline Bond & Distance \\
\hline $\mathrm{Bi} 1-\mathrm{O} 1$ & $2.427(9)$ \\
$\mathrm{Bi} 1-\mathrm{O} 3$ & $2.284(8)$ \\
$\mathrm{Bi} 1-\mathrm{O} 4$ & $2.590(9)$ \\
$\mathrm{Bi} 1-\mathrm{O} 5$ & $2.324(8)$ \\
$\mathrm{Bi} 1-\mathrm{O} 7$ & $2.591(8)$ \\
$\mathrm{Bi} 1-\mathrm{O} 9$ & $2.510(7)$ \\
$\mathrm{Bi} 1-\mathrm{O} 10$ & $2.420(8)$ \\
$\mathrm{Bi1}-\mathrm{O} 11$ & $2.4249(5)$ \\
\hline
\end{tabular}

Consequently the ligands are spreading out in all three directions to the neighbor bismuth cations forming a metal organic framework with very small cavities. An ideal way to understand the structure is to investigate the bismuth-bridging $\mathrm{SO}_{2}$ units and omit the ethylene groups (Figure 2). The resulting three-dimensional network built by the organosulfonate groups is cross-linked to the adjacent bismuth cation, and the MOF-like system can be seen clearly.

Figure 2. The $\mathrm{Bi}-\mathrm{SO}_{3}$ framework of $\mathbf{1}$. The carbon and hydrogen atoms are omitted for clarity.

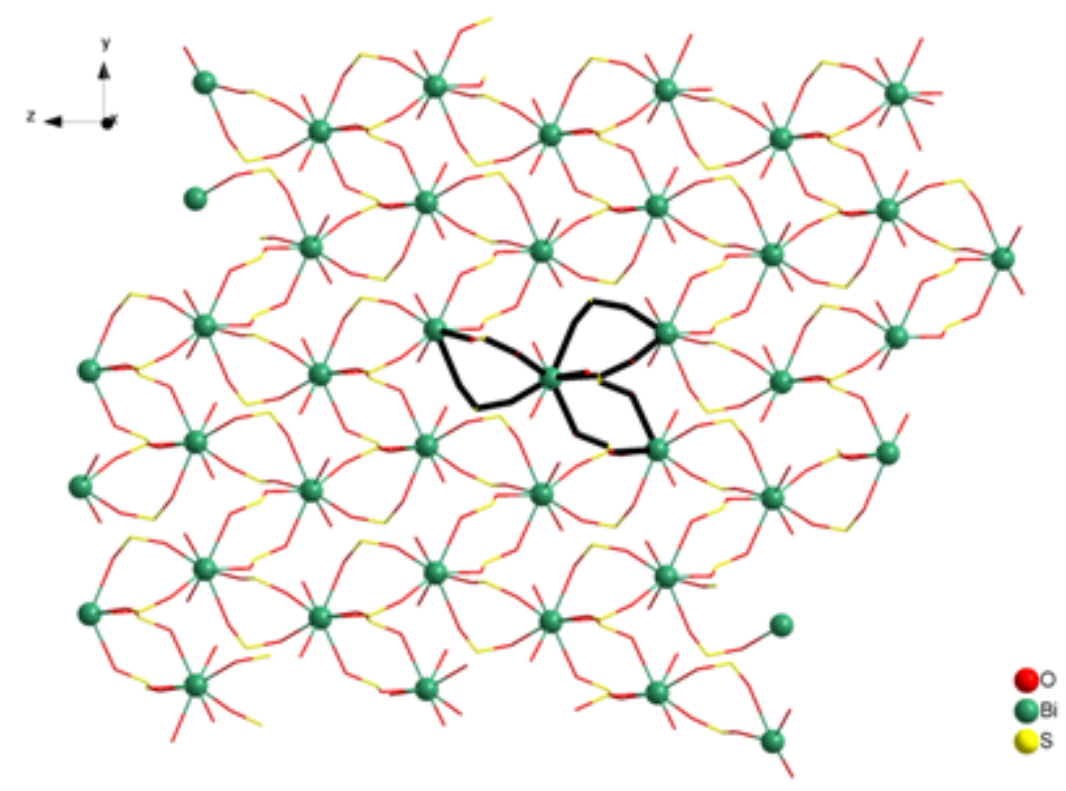

When the whole crystal structure is examined the alternating layers of bismuth cations and ligands becomes visible. Two different sheet systems can be distinguished. One has a large distance of around $6.5 \AA$ as measured between the bismuth layers where the ligand lies stretched out in the $z$-direction (Figure 3). The second system has a shorter distance between the bismuth layers of around $3.8 \AA$ due 
to the ligands that lie in the $x$-direction. The structure does not contain solvent accessible voids, which could be calculated by PLATON Void-Analyser [35].

Figure 3. View of the Bi layers in the $y$-direction (the hydrogen atoms are omitted for clarity).

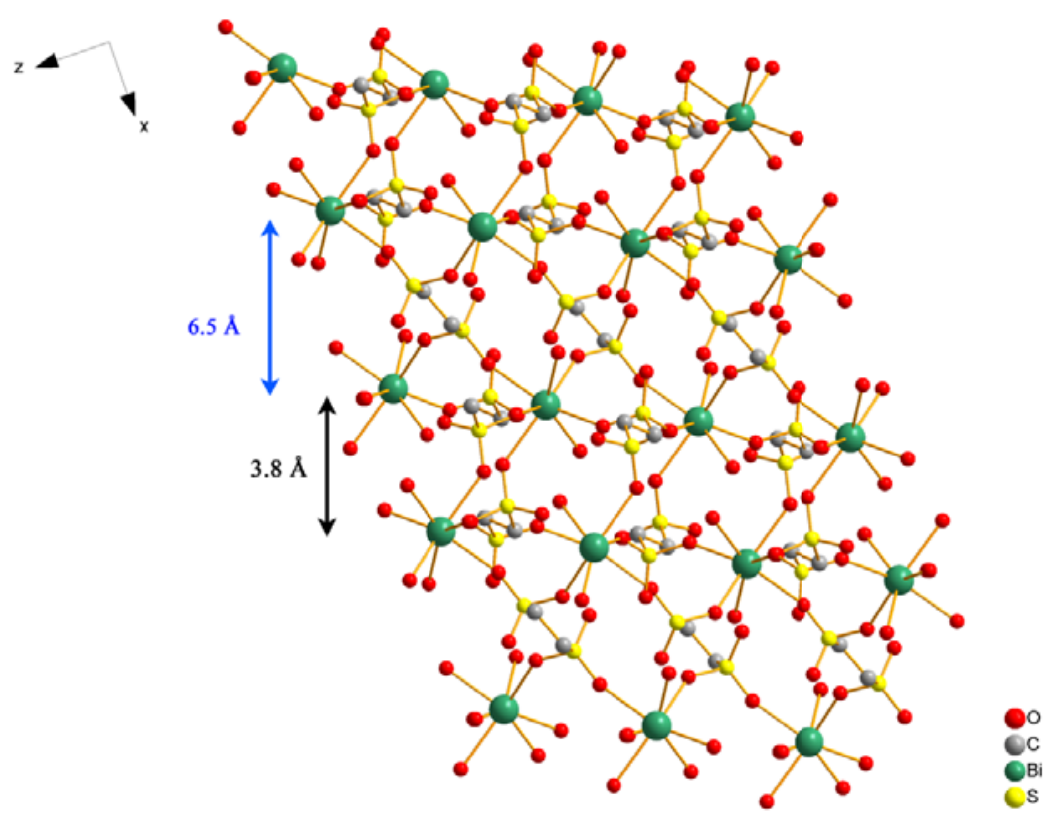

Table 2. Crystal structure data for $\mathbf{1}$.

\begin{tabular}{ll}
\hline Crystal Data & $\mathbf{1}$ \\
\hline Formula & $\mathrm{C}_{3} \mathrm{H}_{10} \mathrm{BiO}_{11} \mathrm{~S}_{3}$ \\
$M_{\mathrm{r}}$ & 527.27 \\
Cryst. size, $\mathrm{mm}^{3}$ & $0.18 \times 0.12 \times 0.07$ \\
Crystal system & monoclinic \\
Space group & $P 2_{1} / \mathrm{c}$ \\
$a, \AA$ & $11.601(2)$ \\
$b, \AA$ & $10.390(2)$ \\
$c, \AA$ & $10.498(2)$ \\
$\beta$, deg & $115.15(3)$ \\
$V, \AA^{3}$ & $1145.3(4)$ \\
$Z$ & 4 \\
$D_{\text {calcd }}, \mathrm{g} \mathrm{cm}{ }^{-3}$ & 3.058 \\
$\mu\left(\mathrm{Mo} K_{\alpha}\right), \mathrm{cm}^{-1}$ & 15.994 \\
$F(000), \mathrm{e}$ & 988 \\
Refl. measd./unique & $12498 / 10592$ \\
Param. refined & 3144 \\
$R(F) / w R\left(F^{2}\right)^{\mathrm{a}}$ (all refl.) & $0.0475 / 0.0283$ \\
GoF $\left(F^{2}\right)^{\mathrm{a}}$ & 1.124 \\
\hline
\end{tabular}


The bulk material of compound $\mathbf{1}$ was confirmed through IR, powder X-ray-diffraction and elemental analyses. Even though compound $\mathbf{1}$ is the main product of the bulk material, a small amount of the compound $\left[\mathrm{Bi}_{6} \mathrm{O}_{4}(\mathrm{OH})_{4}\left(\mathrm{H}_{2} \mathrm{O}\right)_{2}\right]\left[\left(\mathrm{CH}_{2}\right)_{2}\left(\mathrm{SO}_{3}\right)_{2}\right]_{3}[10]$ was always isolated after the first filtration and discarded.

For a better insight into the thermal stability a thermal analysis (TGA) under oxygen was performed: Single crystals of 1 were crushed thus only the pure phase could be investigated: up to the first decomposition peak starting at about $320{ }^{\circ} \mathrm{C}$ only the weight loss of the two coordinated water molecules can be observed (at about $139{ }^{\circ} \mathrm{C}$ and $222{ }^{\circ} \mathrm{C}$, observed $6.7 \%$ calculated $6.8 \%$ ). Higher temperatures led to the decomposition of the organic moiety in one step $\left(320^{\circ} \mathrm{C}-395{ }^{\circ} \mathrm{C}\right.$, observed $35.9 \%$, calculated $35.8 \%$ ), followed by weight gain of $2.5 \%$ till $870{ }^{\circ} \mathrm{C}$, which could be possibly be explained by the adsorption of oxygen molecules. The crystal parameters used in the unit cell determination, and structure refinement parameters are summarized in Table 2.

\section{Experimental Section}

All reagents were obtained commercially and were used in the form that they were received in. The reactions were performed under hydrothermal conditions in air.

$\mathrm{Bi}\left(\mathrm{O}_{3} \mathrm{SC}_{2} \mathrm{H}_{4} \mathrm{SO}_{3}\right)_{1.5}\left(\mathrm{H}_{2} \mathrm{O}\right)_{2}(\mathbf{1})$

A mixture of $\mathrm{Bi}_{2} \mathrm{O}_{3}(1.16 \mathrm{~g}, 2.4 \mathrm{mmol})$, 1,2-ethanedisulfonic acid (2.5 g, $\left.1.3 \mathrm{mmol}\right)$, and $\mathrm{H}_{2} \mathrm{O}(20 \mathrm{~mL})$ was placed into a $25 \mathrm{~mL}$ teflon-lined stainless steel autoclave and kept for 3 days at $170{ }^{\circ} \mathrm{C}$. After slowly cooling the autoclave to room temperature, a colorless solution with a little $\left[\mathrm{Bi}_{6} \mathrm{O}_{4}(\mathrm{OH})_{4}\left(\mathrm{H}_{2} \mathrm{O}\right)_{2}\right]\left[\left(\mathrm{CH}_{2}\right)_{2}\left(\mathrm{SO}_{3}\right)_{2}\right]_{3}$ precipitate [10] had formed. The solution was filtered, and the mother liquor was allowed to evaporate in an open beaker. After two weeks, white crystals had formed. The crystals were filtered, washed with water, and then dried in air. Yield of the pure crystals: $20 \%$.

Single-crystal measurements were carried out on a Stoe IPDS-II diffractometer with a Mo $K_{\alpha}$ sealed tube at room temperature $(\lambda=0.71073 \AA)$. The structure was solved using direct methods and refined in anisotropic approximation using the SHELX program suite [36].

A crystal was selected for single-crystal X-ray diffraction. The composition of the bulk material was confirmed through IR, powder X-ray-diffraction and elemental analyses. $-\mathrm{C}_{3} \mathrm{~S}_{3} \mathrm{BiO}_{11} \mathrm{H}_{10} \cdot 2 \mathrm{H}_{2} \mathrm{O}$ (632.66): calcd. C 6.19 Bi 38.5; found C 5.74, Bi 38.43, TGA: decomposition at $395{ }^{\circ} \mathrm{C}$. FTIR $\left(\mathrm{cm}^{-1}\right)$ : $3467(\mathrm{O}-\mathrm{H}), 2967$ and $2920(\mathrm{C}-\mathrm{C}), 1632(\mathrm{O}-\mathrm{H}), 1457(\mathrm{C}-\mathrm{H}), 1159(\mathrm{C}-\mathrm{C}) 1024(\mathrm{~S}=\mathrm{O}), 895(\mathrm{C}-\mathrm{H})$, $613(\mathrm{C}-\mathrm{S})$.

Powder X-ray diffraction (PXRD) data were recorded using a Bruker ASX D8 Advance powder diffractometer with $C u K_{\alpha}$ radiation $(\lambda=1.5418 \AA)$. Lattice parameters of the bulk material of 1 according to the PAWLEY fit could be found as; $a=11.596, b=110.385, c=10.4926, \beta=115.197$. The reflections of the powder pattern can be assigned to compound 1 (Figure 4, Table S1). 
Figure 4. Experimental powder pattern of the sample in comparison to the theoretical powder pattern of $\mathbf{1}$ as based on the single-crystal structure determination.

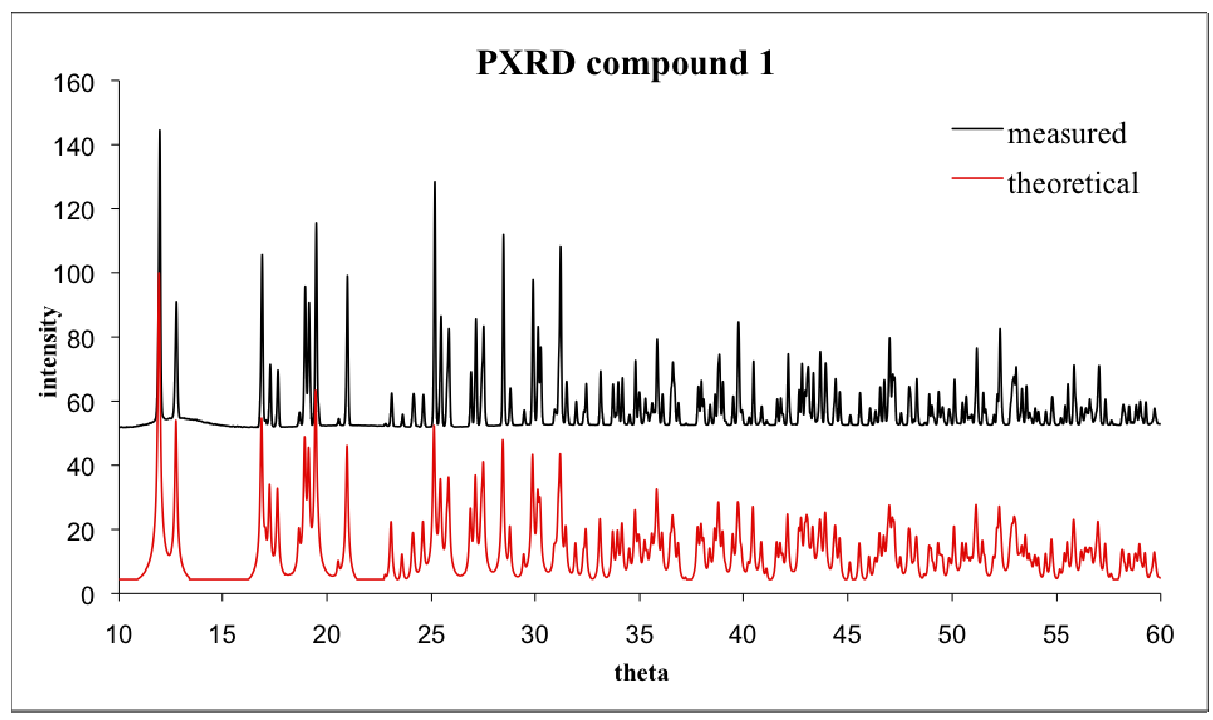

\section{Conclusions}

We have demonstrated that a simple and direct reaction between bismuth oxide and 1,2-ethanedisulfonic acid under hydrothermal conditions yields a new bismuth network structure with an organosulfonic ligand. The bismuth atom has an eight-coordinated environment and is the first three-dimensionally coordinated bismuth ethanedisulfonate framework to be documented.

\section{Acknowledgment}

The authors thank the Swiss National Science Foundation for its generous support.

\section{Conflict of Interest}

The authors declare no conflict of interest.

\section{References}

1. Briand, G.G.; Burford, N. Bismuth compounds and preparations with biological or medicinal relevance. Chem. Rev. 1999, 99, 2601-2657.

2. Csajbok, E.; Baranyai, Z.; Banyai, I.; Brücher, E.; Kiraly, R.; Müller-Fahrnow, A.; Platzek, J.; Radüchel, B.; Schäfer, M. Equilibrium, ${ }^{1} \mathrm{H}$ and ${ }^{13} \mathrm{C}$ NMR Spectroscopy, and X-ray Diffraction Studies on the Complexes Bi(DOTA) and Bi(DO3A-Bu). Inorg. Chem. 2003, 42, 2342-2349.

3. Stavila, V.; Davidoch, R.L.; Gulea, A.; Whitmire, K.H. Bismuth (III) complexes with aminopolycarboxylate and polyaminopolycarboxylate ligands: Chemistry and structure. Coord. Chem. Rev. 2006, 250, 2782-2810.

4. Garje, S.S.; Jain, V.K. Chemistry of arsenic, antimony and bismuth compounds derived from xanthate, dithiocarbamate and phosphorus based ligands. Coord. Chem. Rev. 2003, 236, 35-56.

5. Hanna, T.A. The role of bismuth in the SOHIO process. Coord. Chem. Rev. 2004, 248, 429-440. 
6. Kumar, R.; Mishra, P. Bi (V) organic framework in an asymmetric system: Synthesis, spectroscopic, XRPD and molecular modeling. Main Group Chem. 2007, 6, 85-95.

7. Thirumurugan, A.; Tan, J.C.; Cheetham, A.K. Heterometallic Inorganic-Organic Framework of Sodium-Bismuth Benzenedicarboxylates. Cryst. Growth Des. 2010, 10, 1736-1741.

8. Tran, D.T.; Chu, D.; Oliver, A.G.; Oliver, S.R.J. 3-D bismuth-organic framework containing 1-D cationic inorganic $\left[\mathrm{Bi}_{2} \mathrm{O}_{2}\right]^{2+}$ chains. Inorg. Chem. Commun. 2009, 10, 1081-1084.

9. Cotton, F.A.; Wilkinson, G.; Gaus, P.L. The GroupVB(15) Elements: Phosphorus, Arsenic, Antimony, and Bismuth. In Basic Inorganic Chemistry, 3rd ed.; Rose, N., Herbert, D., Eds.; Wiley and Sons, Inc.: New York, NY, USA, 1995; pp. 399-435.

10. Rogow, D.L.; Fei, H.; Brennan, D.P.; Ikehata, M.; Oliver, S.R.J. Hydrothermal synthesis of two cationic bismuthate clusters: An alkylenedisulfonate bridged hexamer, $\left[\mathrm{Bi}_{6} \mathrm{O}_{4}(\mathrm{OH})_{4}\left(\mathrm{H}_{2} \mathrm{O}\right)_{2}\right]\left[\left(\mathrm{CH}_{2}\right)_{2}\left(\mathrm{SO}_{3}\right)_{2}\right]_{3}$ and a rare nonamer templated by triflate, $\left[\mathrm{Bi}_{9} \mathrm{O}_{8}(\mathrm{OH})_{6}\right]\left[\mathrm{CF}_{3} \mathrm{SO}_{3}\right]_{5}$. Inorg. Chem. 2010, 49, 5619-5624.

11. Thurston, J.H.; Trahan, D.; Ould-Ely, T.; Whitmire, K.H. Toward an general strategy for synthesis of heterobimetallic coordination complexes for use as precursors to metal oxide materials: Synthesis, Characterization, and Thermal Decomposition of $\mathrm{Bi}_{2}(\mathrm{Hsal})_{6} * \mathrm{M}(\mathrm{Acac})_{3}$ $(\mathrm{M}=\mathrm{Al}, \mathrm{Co}, \mathrm{V}, \mathrm{Fe}, \mathrm{Cr})$. Inorg. Chem. 2004, 43, 3299-3305.

12. Andrews, P.C.; Deacon, G.B.; Junk, P.C.; Kumar, I.; Silberstein, M. Synthetic and structural comparisons of bismuth(III) carboxylates synthesized under solvent-free and reflux conditions. Dalton Trans. 2006, 40, 4852-4858.

13. Holmes, R.R.; Schmid, C.G.; Chandrasekhar, V.; Day, R.O.; Holmes, J.M. Oxo carboxylate tin ladder Clusters. A New Structural Class of Organotin Compounds. J. Am. Chem. Soc. 1987, 109, 1408-1414.

14. Asato, E.; Driessen, W.L.; de Graaff, R.A.G.; Hulsbergen, F.B.; Reedijk, J. Synthesis, Structure, and Spectroscopoc Properties of Bismuth Citrate Compounds. Inorg. Chem. 1991, 30, 4210-4218.

15. Adair, B.A.; Neeray, S.; Cheetham, A.K. Role of Chains in the Formation of Extended Framework Tin(II) Phosphates and Related Materials. Chem. Mater. 2003, 15, 1518-1529.

16. Bujoli-Doeuff, M.; Evain, M.; Janvier, P.; Massiot, D.; Clearfield, A.; Gan, Z.; Bujoli, B. New pillared layered gallium phosphonates in the gallium/1,2-ethylenediphosphonic acid system. Inorg. Chem. 2001, 40, 6694-6698.

17. Bruno, I.J.; Cole, J.C.; Edgington, P.R.; Kessler, M.; Macrae, C.F.; McCabe, P.; Pearson, J.; Taylor, R. ConQuest, Version 1.14; Cambridge Crystallographic Data Centre: Cambridge, UK, 2012.

18. Müller, U.; Schubert, M; Teich, F.; Pütter, H.; Schierle-Arndt, K.; Pastré., J. Metal-organic frameworks-prospective industrial applications. J. Mater. Chem. 2006, 16, 626-636.

19. Kitagawa, S.; Kitaura, R.; Noro, S.I. Functional Porous Coordination Polymers. Angew. Chem. Int. Ed. 2004, 43, 2334-2375.

20. Li, H.; Eddaoudi, M.; O'Keeffe, M.; Yaghi, O.M. Design and synthesis of an exceptionally stable and highly porous metal-organic framework. Nature 1999, 402, 276-279.

21. Bauer, S.; Müller, H.; Bein, T.; Stock, N. Synthesis and characterization of the open-framework barium bisphosphonate $\left[\mathrm{Ba}_{3}\left(\mathrm{O}_{3} \mathrm{PCH}_{2} \mathrm{NH}_{2} \mathrm{CH}_{2} \mathrm{PO}_{3}\right)_{2}\left(\mathrm{H}_{2} \mathrm{O}\right)_{4}\right] * 3 \mathrm{H}_{2} \mathrm{O}$. Inorg. Chem. 2005, 44, 9464-9470. 
22. Serre, C.; Groves, J.A.; Lightfoot, P.; Slawin, A.M.Z.; Wright, P.A.; Stock, N.; Bein, T.; Haouas, M.; Taulelle, F.; Férey, G. Synthesis, Structure and Properties of Related Microporous $\mathrm{N}, \mathrm{N}$-Piperazinebismethylenephosphonates of Aluminium and Titanium. Chem. Mater. 2006, 18, 1451-1457.

23. Zhang, L.P.; Zhu, L.G. Influence of neutral amine ligands on the network assembly of lead(II) 4-sulfobenzoate complexes. J. Mol. Struct. 2008, 873, 61-68.

24. Schreuer, J. Crystal structure of thalium sulfanilate semihydrate, $\mathrm{TlH}_{2} \mathrm{C}_{6} \mathrm{H}_{4} \mathrm{SO}_{3} \cdot 0.5 \mathrm{H}_{2} \mathrm{O}$. Z. Kristallogr. New Cryst. Struct. 1999, 214, 313-314

25. Miao, X.H.; Zhu, L.G. Influence of secondary bonds on the network assembly and property in lead(II) 3-sulfobenzoate. Z. Anorg. Allg. Chem. 2008, 634, 335-338.

26. Chandrasekhar, V.; Singh, P. In Situ Generated Hydrated Diorganotin Cations as Synthons for Hydrogen-Bonded and Coordination-Driven 1D-, 2D, and 3D-Assemblies. Cryst. Growth Des. 2010, 10, 3077-3093.

27. Charbonnier, F.; Faure, R.; Loiseleur, H. Structure Cristalline de 1'Ethanedisulfonate-1,2 de Cuivre Tétrahydraté: $\mathrm{Cu}\left[\mathrm{SO}_{3}\left(\mathrm{CH}_{2}\right)_{2} \mathrm{SO}_{3}\right] \cdot 4 \mathrm{H}_{2} \mathrm{O}$. Acta Cryst. 1977, B33, 3342-3345.

28. Charbonnier, F.; Faure, R.; Loiseleur, H. Coordination et Disposition de l'Argent dans l'Ethanedisulfonate-1,2 et le Butanedisulfonate-1,4 d'Argent(I) Cristallisés. Acta Cryst. 1981, B37, $822-826$.

29. Forster, P.M.; Tafoya, M.M.; Cheetham, A.K. Synthesis and characterization of $\mathrm{Co}_{7}(\mathrm{OH})_{12}\left(\mathrm{C}_{2} \mathrm{H}_{4} \mathrm{~S}_{2} \mathrm{O}_{6}\right)\left(\mathrm{H}_{2} \mathrm{O}\right)_{2}-\mathrm{A}$ single crystal structural study of a ferromagnetic layered cobalt hydroxide. J. Phys. Chem. Solids 2004, 65, 11-16.

30. Mootz, D.; Wunderlich, H. Kristallstrukturen von säurehydraten und oxoniumsalzen. IV. dioxonium-äthan-1,2-disulfonat, $\left(\mathrm{H}_{3} \mathrm{O}\right)_{2}\left[\mathrm{O}_{3} \mathrm{SCH}_{2} \mathrm{CH}_{2} \mathrm{SO}_{3}\right]$. Acta Cryst. 1970, B26, 1820-1825.

31. Sartori, P.; Juschke, R.; Boese, R.; Blaser, D. Structure of dihydroxononium alkanedisulfonates. Z. Naturforsch. B 1994, 49, 1467-1471.

32. Fei, H.; Oliver, S.R.J. Two cationic metal-organic frameworks based on cadmium and a,X-alkanedisulfonate anions and their photoluminescent properties. Dalton Trans. 2010, 39, $11193-11200$.

33. Brese, N.E.; O'Keeffe, M. Bond-valence parameters for solids. Acta Cryst. 1991, B47, 192-197.

34. Brown, I.D.; Altermatt, D. Bond-Valence Parameters Obtained from a Systematic Analysis of the inorganic crystal structure database. Acta Cryst. 1985, B41, 244-247.

35. Spek, A.L. Structure validation in chemical crystallography. Acta Cryst. 2009, D65, 148-155.

36. Sheldrick, G.M. SHELXS-97, Program for Structure Analysis, version 97-2; University of Göttingen: Göttingen, Germany, 1998.

(C) 2012 by the authors; licensee MDPI, Basel, Switzerland. This article is an open access article distributed under the terms and conditions of the Creative Commons Attribution license (http://creativecommons.org/licenses/by/3.0/). 